\title{
INSTITUTIONAL CHANGES TO SUPPORT SCHOOL DESEGREGATION: ALTERNATIVE MODELS UNDERLYING RESEARCH AND IMPLEMENTATION
}

\author{
Mark A. Chesler,* \\ James E. Crowfoot, $\dagger$ \\ AND BUNYAN I. BRYANT $\ddagger$
}

I

\section{INTRODUCTION}

This article's focus is on practical alternatives that may be useful in implementing local desegregation plans. It examines program options that may generate community support, alter organizational features of schools, promote classroom innovations, and enable the individuals within schools to change. All the policies and programs suggested here were features of at least one school system's desegregation plan; all have some grounding in scientific theory and research. Finally, all offer considerable promise for helping to achieve one or more of the positive outcomes of desegregated schooling.

Many of the policies and programs we describe and analyze have not been subjected to well-designed social scientific research; that is, there often is little hard evidence regarding their payoffs to students and to others members of the school community. Where research exists, we have so indicated; in some cases, however, we have speculated and drawn policy implications without benefit of empirical data and analysis.

This is not a novel situation. Even the best technical research often leaves policymakers or practitioners unclear as to its exact conclusions and programmatic implications. Also, many practitioners and consumers simply cannot await the complex process of scientific investigation to run its course before acting upon alternatives. Because courts deal with educational remedies to segregation and racial isolation, they too need coherent and feasible programmatic guidelines, whether or not these are supported by conventional scientific analysis. In areas where there have as yet been no direct evaluations, we

\footnotetext{
* Associate Professor of Sociology, The University of Michigan; Executive Director Community Resources, Ltd., Ann Arbor, Michigan.

$\dagger$ Associate Professor in the School of Natural Resources and the Urban Regional Planning Program, The University of Michigan; Project Director, Community Resources, Ltd., Ann Arbor, Michigan.

$\ddagger$ Associate Professor in the School of Natural Resources, The University of Michigan.
} 
use a conceptual framework for our analysis that is rooted in scientific research on conflict and conflict resolution, organizational structures and changes, race relations, and schools and human learning. We have also drawn on other scholars' syntheses of the social science literature as well as on their descriptions of desegregation programs and policies that various schools and communities have attempted. The result is an agenda for sorely needed research on alternatives in desegregation policy and an outline for thoughtful local implementation of desegregation.

In this article we draw attention to the fact that social science research potentially relevant to desegregation policies often has failed to be productive because it has not fully taken into account the assumptions underlying other research and existing policies and programs. The conceptual models and assumptions that guide research studies make important differences in what topics will be selected, which data gathered, and what analyses and interpretations made, as well as which policies and programs will be suggested. Likewise, the particular conceptual models and assumptions that guide practitioners will make a difference in how they approach knowledge and plan for and implement change. Scholars or practitioners who are neither self-conscious nor explicit about their assumptions are often unable to acknowledge alternative conceptions of current reality or future programs, and therefore are hampered in constructing internally consistent analyses. As a result, they have difficulty implementing their ideas in new programs that will both conform to current reality and embody their assumptions satisfactorily.

The first part of this article discusses two contrasting sets of assumptions about communities and organizations in general, and about schools and desegregation in particular. Recent research studies and reports of current programs relevant to planning and carrying out change in desegregated schooling are then reviewed. The focus of the article moves from the community to the school to the classroom, and finally, to individual educators working in the desegregated setting. The article concludes with a review of these suggestions in terms of their general utility and the degree to which they "fit" either one or both of the conceptual models and sets of assumptions discussed.

\section{II}

\section{Alternative Conceptual Models of Social Systems}

Throughout the development of the social sciences, two models of social systems and systemic functioning have predominated. One model-the consensus model-focuses on order and equilibrium as the basic ingredients and virtues of societies; the other-the conflict model-on conflict and change. Advocates of these two models perceive the same phenomena differently, stress different system dynamics, and even direct our attention to different is- 
sues and data. The history of these divisions within social scientific thinking is long, tortuous, and full of debate. ${ }^{1}$

Those who deal with these ideas generally agree that stability and change as well as consensus and conflict are essential and undeniable ingredients of social systems. Thus, these two sets of assumptions are not necessarily polar opposites, nor mutually exclusive interpretations of the world at large; rather, each provides a different perspective for viewing social phenomena and for planning change. Nonetheless, academic theorists, social practitioners, and citizens generally operate on the basis of one or the other of these sets of assumptions.

\section{A. Conceptions of Communities and Organizations}

Scholars and practitioners operating on the basis of the consensus model generally assume that most elements of a community can and do work together. Accordingly, they envision overarching values, which bind different groups together, permit commonly trusted leaders to emerge, and promote cooperation-especially during crises that may accompany community change. People adhering to consensus or order assumptions agree that conflict occurs in communities and organizations but prefer to see conflict as an ephemeral, accidental, or temporary circumstance, one that is neither desirable nor useful.

In contrast, academics and practitioners who work with the conflict model assume that all parts of a community do not cooperate-that these groups may indeed have little experience in working together. They observe an unequal distribution of resources and power that results in different groups with divergent values, different trusted leadership, different ways of relating to key issues and institutions-and, consequently, a history of conflicts with one another. The importance of the structural characteristics that underlie conflicting organizational policies and procedures is also stressed. Some academics locate the primary root of conflict in authority structures; ${ }^{2}$ others stress the universal conflict that arises from mutual task dependence, different statuses, roles, and rewards, and uneven interaction patterns. ${ }^{3}$

1. For some of the best summaries of these polemics, see W. Chambliss, Sociological Readings in the Conflict Perspective (1973); L. Coser, Continuities in the Study of Social. Conflict (1970). R. Dahrendorf identifies the order-consensus-equilibrium model as rooted in, or perhaps reflected by, modern structural-functionalism, the dominant stream of American sociology. Dahrendorf, Toward a Theory of Social Conflict, 2 J. Conflict Resolution 170 (1958). Some see the root of the conflict model in Marxian or neo-Marxian thought. See, e.g., R. Paulston, Conflicting Theories of Social and Educational Change (1976). For the view that the consensus model derives from conservative theory, and the conflict model, from radical theory, see G. Lenski, Power and Privilege (1966).

2. See R. Dahrendorf, Gesellshaft und Freiheit 165-66 (1962). For a discussion of Dahrendorf's theories concerning authority as the origin of social conflict, see A. Oberschall, Social Conflict and Social Movements 33 (1973).

3. See, e.g., Walton \& Dutton, The Management of Interdepartmental Conflict: A Model and Review, 14 AD. ScI. Q. 73 (1969). 


\section{B. Conceptions of Schools}

Advocates of the conflict model find that schools perpetuate inequities and conflicts among local interest groups. Accordingly, they believe schools channel students into traditional economic roles that maintain conditions of privilege for some and poverty for others. What happens in school depends on whether one is male or female; black, brown, or white; rich or poor: the educational system uses sexual, racial, and economic criteria to sort and screen people into limited opportunities for mobility. ${ }^{4}$ Schools also teach obedience to vague and abstract views of the political system and cultivate passive conformity to rules and regulations established by legitimate authority. Conflict model advocates contend that control of the school and its symbols and norms most often lies in the hands of the relatively privileged group of affluent white males. The cultural and social styles of other groups are given short shrift; these must contest with the values of the dominant group for visibility in the school.

Advocates of the consensus model may not agree that the unequal distribution of social rewards is unjust; they would be even less likely to admit that schooling is a mechanism to perpetuate inequality. To the contrary, they believe that schools aid youngsters to overcome inequalities of birth and that economic mobility is attained through universal education. They usually regard unequal outcomes in education as the result of prior student disadvantage or as accidental failures of an otherwise efficient democratic institution. From their perspective, pluralistic political values and symbols are manifest in the school; indeed, schools are the major instrument for building and actualizing an overarching value consensus in society. Under this model, the informal social fabric of American life is open, with interpenetrating linkages among different classes and races; the school encourages (or at least does not prohibit) such interstatus groupings.

Scholars conducting research premised on a consensus model generally argue that historic and pervasive links between family origin and educational attainment, as well as those between educational attainment and occupational status, result from family socialization, technical training, and changing job requirements. Scholars proceeding from a conflict model argue that group struggles have placed a certain class (affluent whites) in control of both occupational and educational systems: these elites control the rules of the

4. This general view is explicated by a group of revisionist historians and analysts of American education. See, e.g., M. Carnoy, Education as Cultural Imperialism (1974); M. Katz, The Irony of Early School Reform (1970); J. Spring, The Sorting Machine (1976); Bowles, Unequal Education and the Reproduction of the Social Division of Labor, in SCHOoling IN A Corporate SoCrety (M. Carnoy ed. 1972). The opposing view is well represented in social scientific literature; for a good summary and comparison, see R. ReHberg \& E. Rosenthal, Class and Merit in The American High School (1978). 
game-the ways in which requirements are developed as well as the ways the game is implemented. ${ }^{5}$

\section{Conceptions of Desegregation}

The two models suggest different goals for school desegregation. For instance, according to the consensus model, desegregation should increase the possibility of order and stability in the society, primarily by altering minorities' feelings of exclusion and injustice. Many programs thus try to increase the ability of minority groups to compete with white groups, especially by raising their educational standards and performance to those of prevailing white norms. This may be accomplished best through assimilative processes, subtle pressures on minorities to accommodate themselves to white norms and standards. Such a goal may also require encouraging whites to overcome the irrationality of historic prejudices and to develop new programs that include more minorities.

On the other hand, according to the conflict model, desegregation should increase the possibility of justice in the society by increasing the status and power of minorities in their attempts to negotiate with more powerful white groups for a fair share of resources. The maintenance of pluralistic goals for performance as well as distinct cultural heritages is essential. From the conflict perspective, a potentially dangerous byproduct of some desegregation programs is that they may cause middle- and lower-class whites, by stressing their competition with minorities, to be less aware of their exploitation by more affluent whites. Desegregation also may dilute the power resulting from concentration of minorities in communities by dispersing minority children throughout the larger white community. The result might be a loss of their sense of cultural uniqueness and the jeopardy of a power base from which to protect and advance minority group interests.

From this discussion, it can be seen that scholars and practitioners proceeding from these two models may well pursue desegregation in different ways and may thus prefer different policy options. Their different assumptions and options are depicted in Table 1. This article, in discussing various policies and programs, calls attention to the role these differences play.

III

Program Options in Implementing Local School Desegregation ${ }^{6}$

Desegregation can be considered a complex process of school change, one requiring that new analysis and programming be done at various levels of a

5. Collins, Functional and Conflict Theories of Educational Stratification, 36 AM. Soc. Rev. 1002 (1971): Squires, Education, Jobs and Inequality: Functional and Conflict Models of Social Stratification in the U.S., 24 Soc. Prob. 436 (1977).

6. See generally M. Weinberc, Minority Students: A Research Appraisal (1977); G. Fore- 

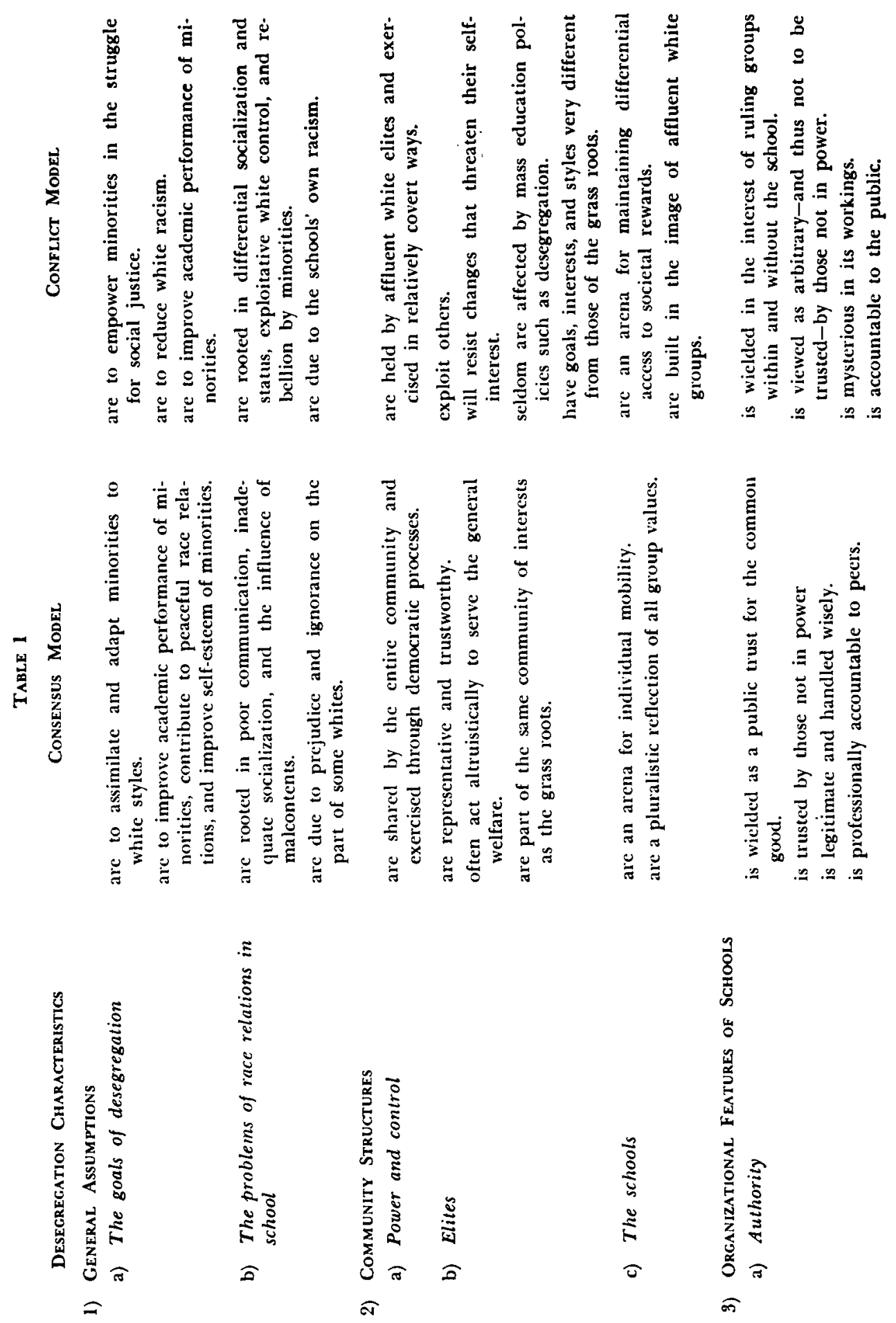
[Vol. 42: No. 4
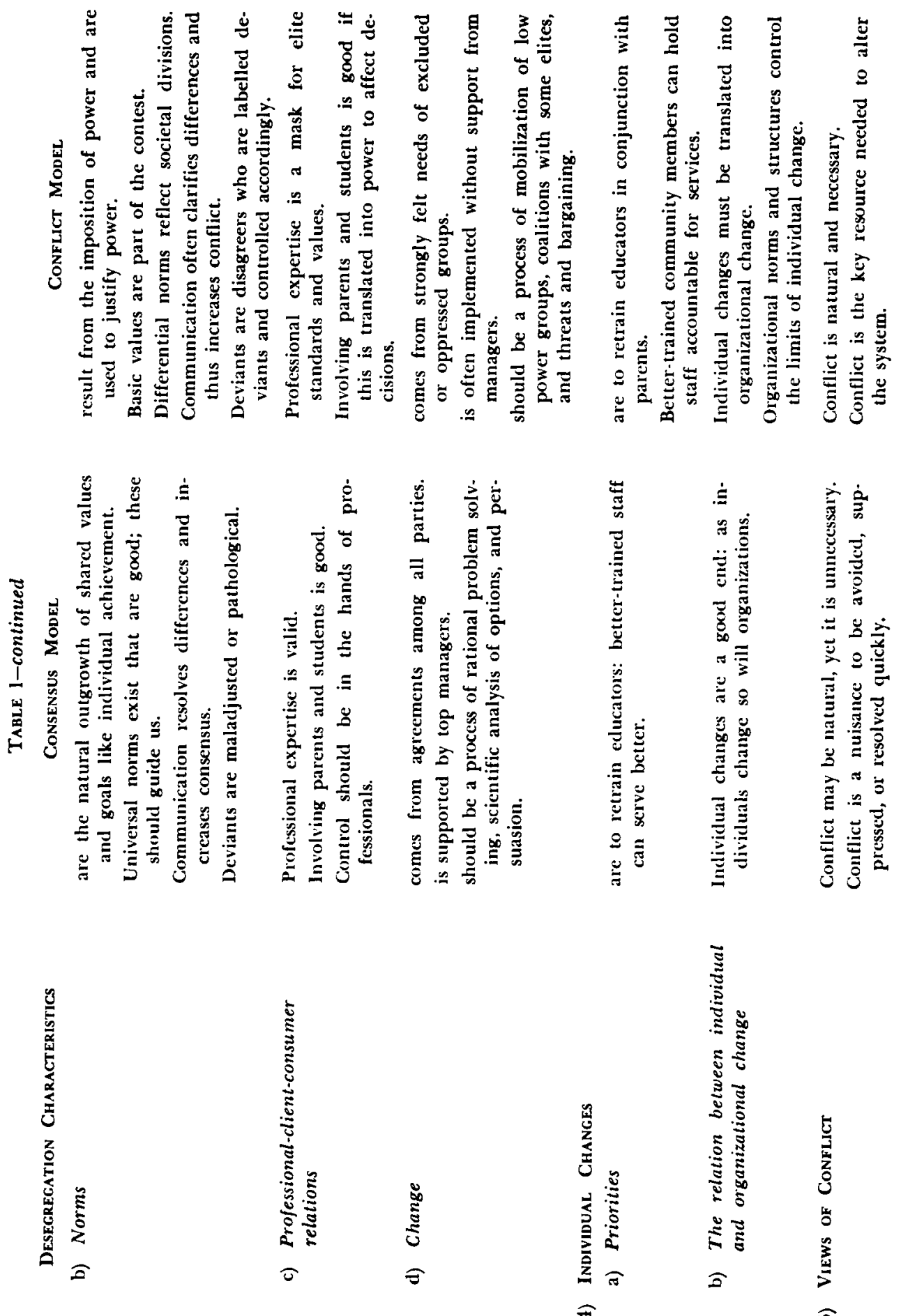
school system's operations. In order for schools to support and advance desegregation, change must occur in the community, in the organization of local schools, in the classroom, and in the individuals who comprise the teaching and learning network. This article examines each of these settings, which otherwise may be seen as levels of intervention and remedy.

\section{A. The Community Context and Resources}

How the school system relates to the local environment is a critical issue for everyone concerned with desegregation. All communities are not alike, of course, and the dynamics of a community and its schools reflect the geography, demography, and tradition of the particular region. Communities also differ in the degree of overt conflict that exists between majority and minority groups and between affluent and poor groups, as well as in the institutional means available for resolving such conflicts.

One strategy for achieving peaceful desegregation is for a representative group from the community to develop broad-based problem-solving skills. People from all racial and class groups may be brought together under a banner of mutually acceptable goals (for example, order, tolerance, and respect for the law). They may be asked to respond to court orders or school problems and to develop local programs or policies for busing, student and parent orientation, or safety. The success of such community planning for schools rests on the ability of all members to use the technical skills of educational professionals, to work together and transcend minor differences, to focus on common problems, and to agree on solutions. This strategy is rooted in the consensus model.

A second strategy endeavors to organize members of particular interest groups that feel they are excluded or suffering as a result of current progress or lack of progress on desegregation plans and programs. The objectives of this approach are the redress of historic injustice and the building of a potent

hand \& M. Ragosta, A Handbook for Integrated Schooling (Office of Education Report No. ETS-PR-76-22, July 1976) (ERIC Document No, 131 154) (hereinafter cited as Forehand \& Ragosta]; G. Forehand, M. Ragosta, \& D. Rock, Conditions and Processes of Effective School Desegregation (Office of Education Report No. ETS-PR-76-23, July 1976) (ERIC Document No. 131 155); J. Coulson, D. Ozenne, C. Bradford, W. Doherty, G. Duck, J. Hemenway, \& N. Van Gelder, The Second Year of the Emergency School Aid Act (ESAA) Implementation (July 1976) (ERIC Document No. 133 362) [hereinafter cited as Second Year ESAA Implementation]; J Coulson, D. Ozenne, S. Hanes, C. Bradford, W. Doherty, G. Duck, \& J. Hemenway, The Third Year of the Emergency School Aid Act (ESAA) Implementation (March 1977) (ERIC Document No. 154 952) [hereinafter cited as Third Year ESAA Implementation]; U.S. Comm'n on Civil Rights, Fulfilling the Letter and Spirit of the Law: Desegregation of the Nation's Public Schools (August 1976) [hereinafter cited as FLSL. We have reviewed 27 of the individual case studies that went into FLSL, and in various places refer to them directly. The authors have also based this section on their own research retrieval efforts, derived from contacts with scholars and practitioners in numerous schools, cities, and related agencies. We appreciate the assistance of Ms. Jan Wright in gathering, recording, and analyzing much of this retrieval. 
organization with which to challenge the power of current decisionmakers. Group members would identify their needs and then develop a coherent vision of what conditions need to be changed. They would look toward allies and uncommitted groups to help generate a credible threat to the ability of school authorities to govern the existing system, and thus to require their inclusion in decisionmaking-not merely consultation in planning. Threatened or actual demonstrations, teacher and student strikes, and parent or service group boycotts are all examples of this conflict model strategy in action.

In any situation it is common to see more than one of these general strategies being used. One group (for example, minority parents) might well combine these strategies (as in a combination of interest group mobilization with appeals to elite groups). These alternatives are reflected in many of the examples of specific tactics described below.

\section{Coalitions}

One way to develop and mobilize community support for local school desegregation is to create a multiracial coalition. Burges makes a useful distinction between two types of coalitions: (1) the citywide "blue ribbon" coalition, which includes members of powerful local organizations representing labor, industry, banking, government, social welfare agencies, and other groups with long-standing channels of influence; and (2) the neighborhood or regional "grassroots" coalition, representing parent groups, churches, and clubs from local areas impacted severely by desegregation plans and programs. ${ }^{7}$

In several cities, local civic leaders have helped organize the resources of various groups and have developed blue ribbon coalitions from among groups with a history of noncommunication or conflict. ${ }^{8}$ In Detroit (PRO-Detroit and New Detroit Inc.), Memphis (Involved Memphis Parents Assisting Children and Teachers), Dallas (Dallas Alliance), and St. Louis (Civic Progress), leaders from various local agencies helped organize and accomplish events ${ }^{9}$ such as:

1. speakers' bureaus sending informed people to local clubs, blocks, and schools to explain the desegregation plan and the need for peaceful cooperation;

2. neighborhood meetings to develop local coalitions;

3. community forums where representatives of various groups could

7. B. Burges, Good Things Can Happen: Your Community Organization and School Desegregation (1978).

8. Community Relations Service and National Center for Quality Integrated Education, Desegregation Without Turmoil: The Role of the Multi-Racial Community Coalition in Preparing for Smooth Transition, 6 (Conference Report, May 19, 1976) [hereinafter cited as Community Relations Service]. The conference brought together leaders of community groups and coalitions from 35 states and the District of Columbia, and 68 national nonprofit organizations.

9. Community Relations Service, supra note 8, at 8-13; Burges, supra note 7. 
present their views on elements of a good desegregation plan;

4. telephone "hotlines" or rumor clinics;

5. media coordination and the placement of positive stories about desegregation;

6. mobilization of influential community persons;

7. generation of resources for special school programs.

The involvement of local community leaders is seen by many as a key step in promoting effective and peaceful desegregation. The U.S. Commission on Civil Rights (USCCR) indicates that in cities where community leaders supported desegregation there were fewer reports of disorder and violence; conversely, disorder and violence were more common where such leaders did not support desegregation.

Of 411 districts where superintendents reported no serious disruptions on the issue of school desegregation, superintendents said:

Business leaders were supportive or neutral in 65 percent.

Political leaders were supportive or neutral in 67 percent.

Religious leaders were supportive or neutral in 87 percent.

Of 95 districts which reported serious disruptions:

Business leaders were supportive or neutral in 27 percent.

Political leaders were supportive or neutral in 30 percent.

Religious leaders were supportive or neutral in 66 percent. ${ }^{10}$

Of course, preventing disorder does not automatically imply positive changes in the quality of desegregation or interracial education, but avoiding violence and sustained disruption obviously is beneficial.

Grassroots coalitions developed in a number of cities as well: Detroit (Coalition for Peaceful Integration), Cleveland (Greater Cleveland Project), Boston (Freedom House Coalition and City-Wide Educational Coalition). More informal grassroots coalitions of white and black parents and community groups were consulted in drawing up administrative plans for desegregation in Tulsa, Oklahoma, and Greenville, Mississippi. ${ }^{11}$

According to Robert Crain and others, the issues that attract blue ribbon or elite collaboration are fairly clear:

Peace-social order and stability;

Prosperity - the stabilization of the economic order required for profitable enterprise-including workers who can work and consumers who can and will buy;

Charity-concern for the welfare of others;

10. FLSL, supra note 6 , at 175.

11. See Oklahoma Advisory Comm. of the U.S. Comm'n on Civil Rights, School Desegregation in Tulsa, Oklahoma 65-66 (Report to the U.S. Comm'n on Civil Rights, August 1977); U.S. Comm'n on Civil Rights, School Desegregation in Greenville, Mississippi 5, 12 (Staff Report, August 1977). 
Progressive reform-concern for gradual change to improve the community. ${ }^{12}$

Issues that attract grassroots coalitions may not be so easily identified; they generally occur at a more local level and are bound by the hope of generating more power when groups unite than any group could have on its own. Bonacich and Goodman report that some issues may be more effective than others in attracting grassroots coalitions of majority and minority parents. For instance, opposition to tracking, effective and fair discipline, and general upgrading of the educational program were probably effective rallying points in Inglewood, California. ${ }^{13}$ Safety could undoubtedly be added to that list for most communities, although the issues will differ as the local setting varies.

Whether organized to exert the power of civic elites or to challenge that power, coalitions offer a good platform from which to launch a broad attack on the problems of community finance and control that undergird local desegregation controversies. Coalitions usually are the key to unlocking other community resources as well, such as the media or volunteer time. One problem, however, is that elites' concerns for community peace all too often fail to address the root problems of racism, educational failure, and exclusion of parents from school decisions. Some scholars and practitioners argue that peace must be threatened and a conflict escalation strategy pursued if meaningful school change is to occur. ${ }^{14}$ Some grassroots coalitions, and many associations of minority parents, advocate this view as well.

Several recent reports have documented the development, activities, and general utility of multiracial coalitions in support of desegregation. However, there is little research that indicates how to establish a local coalition and keep it together in the face of historic competition among agencies, racial and class discrimination and conflict, tensions between blue ribbon and grassroots efforts, and so on. Moreover, there is little evidence from research that indicates the particular and unique contribution of this tactic as distinct from the contributions of other efforts to coordinate elite actions or mobilize community concerns. However, cities that have sustained effective multiracial coalitions of both the blue ribbon and the grassroots variety obviously have a broader base of resources to call upon in support of desegregation.

12. R. Crain, M. Inger, G. McWorter, \& J. Vanecko, The Politics of School Desegregation 210 (1968).

13. E. Bonacich \& R. Goodman, Deadlock in School Desegregation: A Case Study of INGLEWOOD, CALIFORNIA 93 (1972).

14. See, e.g., W. Gamson, Strategy of Social Protest (1975); D. Kirby, T. Harris, R. Crain, \& C. Rossell, Political Strategies in Northern School Desegregation (1973); Lipsky. Protest as a Political Weapon. 62 Am. Pol. Sci. Rev. 1144 (1968); Sprecht. Disruptive Tactics, 14 Soc. Work 5 (1969). On the generally positive role of social conflict, see L. Coser, The Functions of Social Conflict (1966); Dodson, The Creative Role of Conflict Re-examined, 1 J. InTERGROUP REL. 5 (1960); Himes, The Function of Racial Conflict, 45 Soc. ForCes 1 (1966). 


\section{Advisory Boards}

A somewhat different mechanism for accomplishing similar purposes is the school (or school system) advisory board. Substantial efforts in this direction were made in Memphis, Boston, Dade County, Florida, and in seventeen of the twenty-seven cities or counties studied by the U.S. Commission on Civil Rights. ${ }^{15}$ The structures of the boards varied considerably; in some systems one board was established, in others each geographical region or even each local school had a board. In Little Rock, Arkansas, the school board and the NAACP set up a board; ${ }^{16}$ in Stamford, Connecticut, one was established by a small task force operating under the aegis of a federal grant; ${ }^{17}$ and in Ogden, Utah, portions of the local community that felt left out formed their own board. ${ }^{18}$

In some circumstances, these boards were potent actors in school and community decisionmaking efforts; in other cases, they operated merely as sounding boards and conveyors of complaints and information; and in still other cases, they made recommendations that were ignored or resisted by top school officials. An evaluation of the Emergency School Aid Act (ESAA) ${ }^{19}$ indicates that educational policymakers prefer such boards to act as conveyors

15. FLSL, supra note 6 , at $36,51,126$. This source summarizes studies prepared by the U.S. Commission on Civil Rights and its state advisory committees. The individual case studies marshalled by the report may further elucidate this point. The efforts in these 17 cities are discussed in: U.S. Comm'n on Civil Rights, School Desegregation in Kalamazoo, Michigan 1 (August 1977); Oklahoma Advisory Comm. of the U.S. Comm'n on Civil Rights, supre note 11, at 40, 42; U.S. Comm'n on Civil Rights, School Desegregation in Dorchester County, Maryland 5 (1977); U.S. Comm'n on Civil Rights, School Desegregation in Whichita, Kansas 4, 7, 8 (1977); U.S. Comm'n on Civil Rights, School Desegregation in Waterloo, Iowa 12 (August 1977); Texas Advisory Comm. to the U.S. Comm'n on Civil Rights, School Desegregation in Corpus Christi, Texas 75 (May 1977); Connecticut Advisory Comm. to the U.S. Comm'n on Civil Rights, School Desegregation in Stamford, Connecticut 17 (July 1977); U.S. Comm'n on Civil Rights, School Desegregation in Santa Barbara, California 7 (July 1977); U.S. Comm'n on Civil Rights, School Desegregation in Peoria, Illinois 2 (1977); U.S. Comm'n on Civil Rights, School Desegregation in Ossining, New York 3, 4 (1977); U.S. Comm'n on Civil Rights, School Desegregation in Little Rock, Arkansas 14 (June 1977); U.S. Comm'n on Civil Rights, School Desegregation in Colorado Springs, Colorado 3, 8 (February 1977); U.S. Comm'n on Civil Rights, School Desegregation in Providence, Rhode Island 10, 11 (1977); U.S. Comm'n on Civil Rights, School Desegregation in Racine, Wisconsin 4, 7 (June 1977); U.S. Comm'n on Civil Rights, School Desegregation in Portland, Oregon 4 (September 1977); U.S. Comm'n on Civil Rights, School Desegregation in Berkeley, California 4 (August 1977); U.S. Comm'n on Civil Rights, School Desegregation in Ogden, Utah 8 (May 1977).

16. U.S. Comm'n on Civil Rights, School Desegregation in Little Rock, Arkansas, supra note 15 , at 14 .

17. Connecticut Advisory Comm. to the U.S. Comm'n on Civil Rights, School Desegregation in Stamford, Connecticut, supra note 15 , at 17.

18. U.S. Comm'n on Civil Rights, School Desegregation in Ogden, Utah, supra note 15, at 8.

19. Emergency School Aid Act of 1976, Pub. L. No. 94-482, \$§ 321(a)-321(c), 90 Stat. 2216-17, codified at 20 U.S.C. $\$ \S 1603,1606,1619$ (1976); 122 ConG. ReC. S5793 (daily ed. April 14, 1976). ESAA funds are available to school districts that are undergoing desegregation to help reduce the isolation of minority students and to help students overcome the handicaps caused by past isolation. 
of information. Superintendents were asked to choose from among three possible parental and community roles in the process of desegregation:

1. Parents and community should play a major role.

2. Opinions on educational issues should be sought from parents and community.

3. Parents and community should play a minor role. ${ }^{20}$

The ESAA evaluation reports that 12.9 percent of the district superintendents indicated a preference for the first item, 87.1 percent for the second, and none for the third. The "major role" in the first item amounts to a policysetting or decisionmaking role that may require sharing educational power and control. The second item's stress on "opinions sought" maintains power in the hands of professionals and suggests an advisory or communicative role for the community. It should come as no surprise that decisionmakers would favor some community involvement, but only through a means that maintains their own power.

Almost all the advisory boards reported in the literature were multiracial in membership, although many wrestled with problems of minority representation. In Corpus Christi, Texas, for instance, the NAACP representatives as well as some of the other members reportedly resigned from the board because they felt its establishment by the district was an attempt to delay and "to delude the court and people into thinking a meaningful effort at change was being made." 11 In such cases, the use of an advisory board may be similar to other actions of elites, wherein many "cities have been reported to have formally or informally organized a top leadership group that irons out its differences in private, presenting a fairly united front to the community."22

Only two advisory boards studied included students as members-those in Colorado Springs, Colorado, and Racine, Wisconsin. ${ }^{23}$ Several communities experimented with short-lived student advisory boards, but the segregation of this age group into separate boards generally marked their exclusion from potential collaboration with adults.

\section{Preparation for Desegregation}

Interracial coalitions, advisory boards, and other school-community groups often helped in preparation and orientation for desegregation. All but three

20. Second Year ESAA Implementation, supra note 6, at VIII-15, Tables VIII-5 \& VIII-6.

21. Texas Advisory Comm. to the U.S. Comm'n on Civil Rights, supra note 15, at 63

22. Warren \& Hyman, Purposive Change in Consensus and Dissensus Situations, 2 Community Mental Health J. 298 (1966).

23. U.S. Comm'n on Civil Rights, School Desegregation in Colorado Springs, Colorado, supra note 15, at 3; U.S. Comm'n on Civil Rights, School Desegregation in Racine, Wisconsin, supra note 15 , at 7 . 
of the twenty-seven case studies prepared for the U.S. Commission on Civil Rights reported at least some community program of this sort. School officials usually conducted the preparation, but coalitions sometimes played a major role, as did the clergy, media, community relations commissions (Tulsa), ${ }^{24}$ NAACP (Williamsburg County, South Carolina), ${ }^{25}$ and mental health associations (Corpus Christi). ${ }^{26}$

Informational meetings open to the public appeared to be the most common approach to preparing for desegregation. Organized efforts of clergy to speak to their congregations also were quite common, as were rumor control hotlines. ${ }^{27}$ In Santa Barbara, California, large displays promoting the value of integrated schooling were shown in several local banks and larger businesses; space for comments encouraged response from citizens. ${ }^{28}$ In Kirkwood, Missouri, over 350 "coffees" were held where school administrators came and answered local citizens' questions, ${ }^{29}$ and in Minneapolis, Minnesota, an estimated 150 or more local meetings were held prior to desegregation. ${ }^{30}$

School and community preparation did not go smoothly in all cases, especially when certain community groups had special needs and concerns, or when school collaboration was difficult to obtain. For instance, in Corpus Christi, the school system evidently was reluctant to provide aid to community meetings for Hispanic groups. Nonschool agencies went ahead with orientation sessions, even though the school system argued that their efforts were premature. ${ }^{31}$

\section{Monitoring}

One of the ways some community groups obtained adequate information about school actions was through monitoring programs. This tactic involved community volunteers, or on ocassion a paid staff, keeping tabs on the school system's progress in desegregation. Sometimes community groups initiated this effort; sometimes school systems invited community monitoring; and sometimes such activities were established by a court order. We do not yet have enough experience with this community option to know what institu-

24. Oklahoma Advisory Comm. of the U.S. Comm'n on Civil Rights, supra note 11, at 46, 50-51.

25. U.S Comm'n on Civil Rights, School Desegregation in Williamsburg County, South Carolina 12 (June 1977).

26. Texas Advisory Comm. to the U.S. Comm'n on Civil Rights, supra note 15, at 7, 62, 64 .

27. See Community Relations Service, supra note 8, at 10, 14-15.

28. U.S. Comm'n on Civil Rights, School Desegregation in Santa Barbara, California, supra note 15 , at 7 .

29. U.S. Comm'n on Civil Rights, School Desegregation in Kirkwood, Missouri 9 (July 1977).

30. U.S. Comm'n on Civil Rights, School Desegregation in Minneapolis, Minnesota 8 (May 1977).

31. Texas Advisory Comm. to the U.S. Comm'n on Civil Rights, supra note 15, at 4-16. 
tional base, what internal format, or what set of data gathering and reporting activities makes the most sense.

We are beginning to observe, however, examples of monitoring activities of different kinds being used in different communities. For instance, reports from several cities (Santa Barbara and Berkeley, California, Kirkwood, Missouri, and Providence, Rhode Island) described programs in which parents rode buses and observed racial interactions on buses and in playgrounds. ${ }^{32}$ In other cities (Denver, for example), monitors collected information about bus seating or lunchroom segregation, and identified potential trouble spots. ${ }^{33}$ When monitoring guidelines are established by or with the supervision of educators, they often caution against intervention, limit the areas of inquiry, stress the locus of control in the school system, and require data to be turned over to the administration. Such approaches to monitoring generally require sympathetic and helpful leadership by educators and public officials, and a supportive and trusting response from the community.

If educational and public officials are not providing vigorous and positive leadership to the desegregation effort, or if these officials wish to minimize the involvement of parents and community members, then monitoring may require a different approach, and community groups may need to help identify problems and raise issues to a level of public awareness. In some cases, even drawing public attention to issues has not been sufficient, and new forms of power have been used to turn a "condition" into a notable "problem" -typically by demanding attention and action. The importance of this approach is reflected in data gathered by Zeigler and Boss, which show that $\mathbf{5 0}$ percent of the superintendents and board members in their sample of interracial school districts recognized no racial problems:

School governors apparently do not recognize such (racial) difficulties as being "problems," a fact that undoubtedly upsets the black citizen. Rather, school governors appear to recognize racial problems only where major issues or crises have evolved. ${ }^{34}$

Monitoring activities that gather data on a school system's positive steps (or lack thereof) to counter racial and economic discrimination could be used as part of a broader campaign to hold these actors and institutions accountable to parents and community groups. Without such early warning signs, it may

32. U.S. Comm'n on Civil Rights, School Desegregation in Santa Barbara, supra note 15, at 11; U.S. Comm'n on Civil Rights, School Desegregation in Kirkwood, Missouri, supra note 29, at 11 ; U.S. Comm'n on Civil Rights, School Desegregation in Berkeley, California, supra note 15, at 15; U.S. Comm'n on Civil Rights, School Desegregation in Providence, Rhode Island supra note 15.

33. See, e.g., Senior High Monitor Report form, in Community Education Council (Denver, Colorado), School Monitor Information Packet (1976) (mimeographed).

34. Zeigler \& Boss, Racial Problems and Policy in the American Public Schools, 47 Soc. of Educ. 319,322 (1974). 
take a crisis or highly escalated conflict to turn official attention to deeply felt problems, and perhaps to initiate change.

\section{Developing Other Resources}

Another popular community change effort relevant for desegregation is the development of new resources for schools. Many resources less obvious than money are important, including the volunteer labor of parents and community groups to help teach new classes, monitor buses, playgrounds, and lunchrooms, staff innovative field trips, or expose students to various previously hidden segments of the community. As parents and community members contribute their resources to school affairs, whole segments of the community that have seldom encountered each other may discover the extent of their misconceptions, fears, differing styles, or conflicting expectations about each other. The results can often be problematic, as difficulties can be compounded, or underlying conflicts escalated. In Dade County, special training programs were established to help community members examine their relation to potential allies and opponents as they worked in local schools. ${ }^{35}$ Efforts were made to sharpen parents' skills in running meetings, engaging in collaborative problem solving, gathering data, and understanding school issues. Training programs for community volunteers led by school personnel have been reported in many other cities undergoing desegregation.

\section{Relevance of the Conflict and Consensus Models}

What assumptions do these various programs make about the community context within which desegregation takes place? Adherents of the consensus model generally view desegregation as a process occurring within a more or less pluralistic environment, one with progressively more egalitarian adjustments to counter historic racial and class stratification. Adherents of the conflict model usually believe that desegregation occurs within a rather highly separated and stratified environment, one in which power is concentrated in affluent white groups. They perceive racial and class oppression to be systematic and coercive, with relatively minor progress being made toward true social equality or justice. Scholars and practitioners viewing desegregation from a conflict perspective suggest that the political structure governing schools is dominated most often by property-owning classes, including the social and business elite of the community. These elites favor (and get) stability and maintenance of their interests in the operation of schools. Those whose perspective is the consensus model argue that such elites do not necessarily exert

35. Personal correspondence, Dr. L. Pugh, Department of School-Community Participation, Dade County Public Schools (Sept., 1977) on file with Mark Chelser, at Community Resources, L.td. 
control over local communities and, therefore, do not control their schools. Consensus model advocates contend that the various portions of a community can participate democratically in electing a school board, vote on millage elections, or gain access to educational leaders. Thus, access to schools would be easy for most parents, and their efforts accepted and supported by school officials. From the consensus perspective, advisory boards are useful adjuncts to professional decisionmaking, and various groups can expect that there will be a rapid response to their concerns.

Those who operate on assumptions consistent with the conflict model are not so sanguine about cooperation between community and school. They expect access to schools to be reserved for the powerful and influential community members and difficult for lower-class or minority parents. They often consider advisory boards a sham, a way of masking fundamental conflicts between professional control of the schools and community members' attempts to advance their own interests and needs. Such boards constantly substitute participation for power and distract community members from the need to exert influence on school officials. Failing to get rapid and forthright response by educators, community groups adopting a conflict strategy must mobilize to exert influence, perhaps even to generate crises for educators. That this strategy is indeed being used is borne out by many reports. For instance, of the superintendents included in the ESAA basic school sample, 29 percent reported protests, demonstrations, and sit-ins; 39 percent reported legal actions filed against school leaders; 10 percent reported boycotts; 16 percent reported destruction of school property; and 19 percent reported closing of schools due to intergroup tension. ${ }^{36}$

Should community reaction and resistance be expected? And where might it come from? The two models again lead to different answers. Adherents of the consensus model of desegregation and school change generally downplay the relevance of professional resistance to desegregation or see it as a problem of miscommunication-correctable by open discussion and problem-solving activities. Antidesegregation groups in the community usually are seen as uninformed or benighted and, perhaps, to be acting out of prejudice. Adherents of the conflict model of desegregation anticipate that the clash of community values and interests will generate resistance to racial and educational change. Some of that resistance might well come from educators seeking to maintain their own positions of power and their own traditions of professional behavior. Some of it might come from antidesegregation community groups, or from other parents and students (white or minority) who cherish values and interests not met by a desegregation agenda. The social scientific and educa-

36. Second Year ESAA Implementation, supra note 6, at VIII-20. Events of this sort were reported in every case study prepared for FLSL, supra note 6. 
tional literature on desegregation has not yet provided us with good data on the interest group bases of such community conflicts or on the ways prodesegregation forces can out-mobilize, withstand, or create compromises and coalitions with resistant groups.

In general, it appears easy for community members and many researchers to ignore local racial patterns or assume a consensus on race-related issues, and concentrate instead on the schools' problems. But educators and scholars proceeding from a conflict model stress that sustained changes in schools probably will not occur unless corollary changes occur in the organization of municipal finance, jobs, housing, social services, crime control, transportation, and other factors determining the quality of life in a community. If the national and local politico-economic structure is involved in the maintenance of societal racism, then racism in education cannot be altered independently of change in these surrounding social structures.

\section{B. Organizational Structures and Processes of Schools}

Many educators and community leaders believe that the present structure of school organization supports a variety of cultural styles, promotes intellectual diversity, and operates in a relatively fair manner. They believe a wellfunctioning professionalism will serve the interests of most if not all students, and that it certainly will serve those interested in an education. In their view, though some minor alterations are necessary, the basic structure does not need reform. These views are generally consistent with the consensus model of school and social organization.

Others, using the conflict model, view the school as an instrument used by affluent whites to dominate the poor and minority groups. Professionals are employed to manage these systems and to impose dominant cultural patterns onto the lives of all students. The selection and socialization patterns accompanying professionalism alienate educators from minorities and poor people. From this perspective, efforts to desegregate and thus introduce alternative cultures cannot be accommodated within the professional bureaucracies of schooling as currently organized.

Attempts to study and alter the organizational structures and processes of schools often collect various factors together into a single variable or variable cluster called "climate." Weinberg presents the general case for making changes in this cluster during desegregation, noting that: " 'experiments' are usually confined to changing the racial composition of the classroom or the school. Teaching methods and school organization remain the same. Implicitly, this assumes that existing methods and structures are conducive to educational growth." ${ }^{37}$ Forehand and Ragosta suggest, in a manual they have pre-

37. M. WEINBERG, supra note 6 , at 169. 
pared for educators, that the key organizational "methods and structures" of effective desegregated schools include:

1. multi-ethnic teaching methods;

2. home and school communication, cooperation and confrontation when necessary;

3. equitable rules and regulations for students;

4. principal leadership;

5. human relations activities in the student curriculum;

6. staff retraining;

7. interracial achievement grouping;

8. fairness and equity throughout the school. ${ }^{38}$

Not all of these factors can be treated comprehensively within the scope of this article, but the program options relevant to most of these factors are discussed here in the context of the roles of principals, staffs, and students. Among these are options in rules and regulation and in curriculum (including content and grouping procedures).

\section{Role of the School Principal}

Most observers agree on the importance of the principal to the successful desegregation of a school. ${ }^{39}$ To reduce this role to a set of personal characteristics or background factors may be impossible; but the role probably can be expressed in terms of skills, role relations, and acts of leadership. For instance, when St. John stresses the need for "affirmative administrative leadership" in desegregation, she means a principal's unequivocal commitment to making positive changes, actively selecting and training a school staff to be competent in interracial instruction, and working vigorously to structure a positive interracial climate within the school. ${ }^{40}$

As the senior educator in the school, a principal can facilitate desegregation in several different ways. ${ }^{41}$ She or he can: (1) help organize staff resources in ways that build an instructional team devoid of competition and racial bickering and characterized instead by the sharing of competencies, the supporting of new ideas, and the promotion of positive interaction; (2) act as a professional leader to provide feedback to teachers, consult on the development of new pedagogy, reward innovative classroom efforts, and invite or require staff participation in school leadership functions; (3) be a direct and indirect teacher of students, both as an instructor and as a model of concerned and

38. Forehand \& Ragosta, supra note 6, at 28-57.

39. See, e.g., Orfield, How to Make Desegregation Work: The Adapation of Schools to their NewlyIntegrated Student Bodies, 39 Law \& Contemp. Prob., Spring 1975, at 314.

40. N. St. John, School Desegregation: Outcomes for Children 124 (1975).

41. See M. Chesler, C. Jorgenson, \& P. Erengerg, Planning Education Change (1970). 
fair-minded educational authority; (4) assist the school staff in establishing effective communication with, and accountability to, parents and other community members; (5) help organize the community in support of desegregation and in support of new student, staff, and parent programs to increase the effectiveness of desegregation; and (6) act as an agent of change in the larger community and in the upper echelons of the school system, protecting local innovations and promoting changes throughout the system. This last role is often overlooked and appears especially important: Forehand, Ragosta, and Rock stress the ways a principal's influence in the school system may help gain added resources for the local school. ${ }^{42}$

Although these and similar priorities make good sense, there has not been any good research on how a principal can accomplish these role behaviors. Research that correlates attitudes of principals, or even their practices, to certain staff or student outcomes still fails to examine how to implement such suggestions. A series of studies on the ways in which successful (and not so successful) principals operate in desegregated settings is needed. Ethnographic studies probably would be most helpful in filling the gaps in our knowledge.

As desegregation creates and highlights new relations between schools and the community and influences the leadership expectations of different groups, principals may experience quite contradictory role demands and increased pressures from various groups. These issues are exacerbated when the principal is a member of a racial minority. Buxton and Prichard provide a sensitive and detailed narrative of the ways community groups, administrative peers and superiors, and local staff subordinates have tried to subvert the authority of black principals. ${ }^{43}$ Their study of thirty current and former black principals, about 75 percent of their total population in one Southern state, indicated two major lines of attack: erosion of the principal's authority, and erosion of the minority community's unity. Examples of the erosion of the principal's authority include:

1. making black principals assistants to white principals;

2. promoting black principals to do-nothing roles (with salary increases);

3. placing pressure on black principals to resign;

4. hiring others to do part of the principal's task;

5. permitting or encouraging white staff to resist the principal's leadership.

Examples of the erosion of the minority community's unity include:

42. Forehand, Ragosta, \& Rock, supra note 6, at V; Forehand \& Ragosta, supra note 6, at 57.

49. Buxton \& Prichard, The Power Erosion Syndrome of the Black Principal, 15 InTEgRaTED Evuc., May-June 1977, at 9 . 
1. creating competition among black educators;

2. promoting compliant blacks within the system;

3. permitting or encouraging blacks to appeal to higher level whites.

Without administrative support at higher levels, minority administrators experienced sabotage and disrespect and were unable to exercise positive authority at the local school level. ${ }^{44}$

More optimistic reports from Dorchester County, Maryland, and Nashville-Davidson County, Tennessee, indicated that efforts to create majorityminority teams for the administration of desegregated schools were successful. ${ }^{45}$ Interracial leadership teams may stand as models for staff and student organization and begin to present new visions of racial equity and shared power in organizations. But this is no easy task, and we know little about how to make this kind of innovation work. At the very least, these efforts require a great deal of support at the higher levels of administration and perhaps complementary encouragement from community coalitions and fellow staff members. It also requires of the involved administrators new skills as well as the commitment to pioneer a difficult innovation.

\section{Staff Roles}

Changing the nature and operation of the educational staff appears to be another appropriate tactic for facilitating school desegregation. At least six of these case studies conducted for the United States Commission on Civil Rights (USCCR) indicated that new and specialized staff roles had been created to assist in the desegregation process. Among the most common titles are: human relations officer, community liaison officer, student advocate, ombudsperson, teacher aide, bus monitor, multicultural expert and counselor. ${ }^{46}$

Obviously these additional staff members buttressed the school system's resources to deal with a variety of the community and organizational changes discussed herein. However, there is little sound evidence indicating they were helpful in and of themselves, or which new roles were most useful. In fact, the titles (and the studies) reveal very little about what they actually did or

44. Id. at $9-14$.

45. U.S. Comm'n on Civil Rights, School Desegregation in Dorchester County, Maryland, supra note 15; U.S. Comm'n on Civil Rights, School Desegregation in Nashville-Davidson County, Tennessee 16-18 (June 1977).

46. U.S. Comm'n on Civil Rights, School Desegregation in Waterloo, lowa, supra note 15, at 24; U.S. Comm'n on Civil Rights, School Desegregation in Santa Barbara, California, supra note 15, at 7; Connecticut Advisory Comm. to the U.S. Comm'n on Civil Rights, supra note 15, at 57; U.S. Comm'n on Civil Rights, School Desegregation in Kirkwood, Missouri, supra note 29, at 10; U.S. Comm'n on Civil Rights, School Desegregation in Colorado Springs, Colorado, supra note 15, at 11; U.S. Comm'n on Civil Rights, School Desegregation in Ogden, Utah, supra note 15, at 3. 
how they generated support from the school and the community to do it. The most that can be concluded is that such innovations can be useful-either in broadening communication between the community and the school or in increasing community pressure and presence in the school-if there is support from other staff members (such as the principal, superintendent, and teacher leaders) and from standard organizational procedures (such as meetings where those in the innovative roles can actively participate or committees where newly identified grievances are dealt with). Otherwise, these new roles and their functions will fail to be institutionalized and will exist as token reforms that can be scapegoated and discarded easily at some later date.

Many new staff members, especially those in nontraditional roles, require careful preparation for their jobs. In addition, schools often have hired and used ancillary staff without paying close attention to their special contributions to desegregation, as in the cases of bus drivers, custodians, and clerical staff. In Denver, however, school bus drivers were given special training in responding to desegregation incidents, and parents were given explicit instructions in how to prepare their youngsters for the busing experience. ${ }^{47}$ These staff members have substantial interaction with students and parents and often can play critical roles in creating positive relations between schools and the community. If they are not treated as important staff members, and if their relevance to overall policy and program is not acknowledged, much of their usefulness can be wasted.

Nine of the case studies produced by the USCCR indicate that since the advent of desegregation, they had successfully increased the local percentage of minority professional staff members. ${ }^{48}$ At least fifteen of these studies mentioned successful efforts to move staff members to different schools to establish greater staff racial balance. ${ }^{49}$ In several communities, moreover, courts

47. Department of Transportation, Denver Public Schools, Handbook Supplement for Bus Assistants (1976).

48. U.S. Comm'n on Civil Rights, School Desegregation in Kalamazoo, Michigan, supra note 15, at 11; Oklahoma Advisory Comm. of the U.S. Comm'n on Civil Rights, supra note 11, at 31; U.S. Comm'n on Civil Rights, School Desegregation in Waterloo, Iowa, supra note 15, at 30; Connecticut Advisory Comm. to the U.S. Comm'n on Civil Rights, supra note 15, at 29; U.S. Comm'n on Civil Rights, School Desegregation in Minneapolis, Minnesota, supra note 30, at 13, 95; U.S. Comm'n on Civil Rights, School Desegregation in Colorado Springs, Colorado, supra note 15, at 8; U.S. Comm'n on Civil Rights, School Desegregation in Berkeley, California, supra note 15, at 8, 20; U.S. Comm'n on Civil Rights, School Desegregation in Williamsburg County, South Carolina, supra note 25, at 3, 7; U.S. Comm'n on Civil Rights, School Desegregation in Portland, Oregon, supra note 15, at 2.

49. U.S. Comm'n on Civil Rights, School Desegregation in Kalamazoo, Michigan, supra note 15, at 11; Oklahoma Advisory Comm. of the U.S. Comm'n on Civil Rights, supra note 11, at 4; U.S. Comm'n on Civil Rights, School Desegregation in Nashville-Davidson County, Tennessee, supra note 45, at 10; U.S. Comm'n on Civil Rights, School Desegregation in Dorchester County, Maryland, supra note 15, at 12; U.S. Comm'n on Civil Rights, School Desegregation in Wichita, Kansas, supra note 15, at 7; U.S. Comm'n on Civil Rights, School Desegregation in Raliegh County, West Virginia 14 (1977); U.S. Comm'n on Civil Rights, School Desegregation in Newport 
have ordered greater racial equity in hiring, in replacement hiring, or in firing. It seems essential that each local school system develop and pursue an affirmative action plan for the recruitment, selection, placement, and maintenance of minority staff members, including administrators.

The reason for such a priority may not be that minority teachers are more caring or effective instructors of minority youth: the answers that research offers on that proposition are by no means clear. On some matters, such as language and culture, minority staff members may have special and irreplaceable expertise; in other matters they are no different from majority staff members in their relation to youngsters. But racial equity in professional teaching ranks is an important signal to the community and the school system of a concern for equity. Also an interracial staff that can surmount traditional stereotypes may be able to present a good model of interracial harmony and cooperation to students and community members alike. It is not easy to accomplish such staffing patterns, for racism within the staff is just as stubborn as elsewhere; but it is a meaningful option open to the desegregated school.

Affirmative action programs cannot end with new hiring practices even if these are successful. If organizational racism is maintained subsequent to hiring, and if power structures fail to support new personnel, sabotage and rejection can be expected. Forehand, Ragosta, and Rock indicate the importance of friendly and open interpersonal relations among teachers as a characteristic of effectively desegregated schools. Moreover, they note that the principal plays a major role in setting the tone for positive relations among the staff: "High schools that have good race relations tend to have principals that are evaluated highly by teachers." 50

These patterns of staff employment, deployment, and interaction can be expected to filter into the classroom and to be reflected in staff attitudes toward youngsters and their achievement. ${ }^{51}$ Administrative leadership in pursuit of positive staff actions has taken many forms: the USCCR case study of Berkeley reports that when desegregation began in 1967, the superintendent

News, Virginia 8 (1977); U.S. Comm'n on Civil Rights, School Desegregation in Minneapolis, Minnesota, supra note 30, at 14; U.S. Comm'n on Civil Rights, School Desegregation in Ossining, New York, supra note 15, at 8; U.S. Comm'n on Civil Rights, School Desegregation in Little Rock, Arkansas, supra note 15, at 8; U.S. Comm'n on Civil Rights, School Desegregation in Colorado Springs, Colorado, supra note 15, at 8; U.S. Comm'n on Civil Rights, School Desegregation in Kirkwood, Missouri, supra note 29, at 8; U.S. Comm'n on Civil Rights, School Desegregation in Williamsburg County, South Carolina, supra note 25, at 3; U.S. Comm'n on Civil Rights, School Desegregation in Greenville, Mississippi 3 (1977); U.S. Comm'n on Civil Rights, School Desegregation in Ogden, Utah, supra note 15, at 7 .

50. Forehand, Ragosta, \& Rock, supra note 6, at v.

51. For documentation of the importance of staff attitudes, see R. Bloom, A. Davis, \& R. Hess, Compensatory Education for Cultural Deprivation (1965); G. Noar, The Teacher and Integration (1966); R. Rosenthal \& J. Jacobsen, Pygmalion in the Classroom (1968); N. St. JoHN, supra note 40, at 125; M. WEINBERG, supra note 6. 
asked any staff member who opposed desegregation to leave the district. ${ }^{52}$ Moreover, parents and students in numerous schools and communities have protested the degrading and deleterious aspects of staff racism and minority staffing procedures. ${ }^{53}$

\section{Student Roles}

In a review of research undertaken five years ago, Cohen argued that "the school, as presently structured, does not present many opportunities for interracial interaction." 54 And, we might add, certainly not for the type of interracial interaction that is necessary to support positive racial relations. Students' social groups are segregated, and academic groups are often tracked or organized informally in ways that promote status inequality and emotional distance. To address this problem, attempts to alter traditional patterns of social interaction among students and between students and staff members were made in at least ten of the twenty-seven cities studied by the USCCR. Some cities established training programs for students or biracial student problemsolving committees, or both (Boston, Denver, Tampa, Providence, and Nashville-Davidson County). ${ }^{55}$ In Kalamazoo and Providence, biracial student committees met with their local principals and teachers to plan greater minority student access to school activities. ${ }^{56}$

Although there are many reports of new programs aimed at altering student attitudes, norms, and patterns of behavior, relatively few appear to involve youth in significant ways in the design and implementation of these programs. This omission is quite consistent with the traditional view of student roles and with traditional school organization patterns, which generally do not share programmatic authority or control with youth. But during desegregation, when the youth community itself is undergoing rapid changes, it may be even more important to generate new roles for youth in schools.

Weinberg's review of the literature on desegregation identifies several studies that indicate that "student involvement and responsibility for the school's program was ... vital" in producing positive racial interactions. ${ }^{57}$

52. U.S. Comm'n on Civil Rights, School Desegregation in Berkeley, California, supra note 15, at 7 .

53. Oklahoma Advisory Comm. of the U.S. Comm'n on Civil Rights, supra note 11, at 81; U.S. Comm'n on Civil Rights, School Desegregation in Waterloo, lowa, supra note 15, at 8; U.S. Comm'n on Civil Rights, School Desegregation in Portland, Oregon, supra note 15, at 12; Texas Advisory Comm. to the U.S. Comm'n on Civil Rights, supra note 15, at 41 .

54. Cohen, The Effects of Desegregation on Race Relations, 39 LAw \& Contemp. Pros., Spring 1975 , at $271,290$.

55. FLSL, supra note 6, at 253. See also M. Connolly, New Student Government to be Formed, Parents United, Sept. 1976, at 4 (prepared by the City-Wide Parents Advisory Council) (newsletter of the Boston Public School Parents).

56. U.S. Comm'n on Civil Rights, School Desegregation in Kalamazoo, supra note 15, at 8; U.S. Comm'n on Civil Rights, School Desegregation in Providence, Rhode Island, supra note 15.

57. M. WeINBERG, supra note 6, at 212. 
Coulson and his co-workers report that among secondary students, "views of their control over the environment, as measured by the 'locus of control' scale, was positively associated with reading and math outcomes." 58 Thus, these researchers suggest that students be given more control over aspects of the school curriculum and instructional materials. ${ }^{59}$ Obviously, the implications for new student roles are far wider than that and could affect an entire series of organizational factors that currently exclude youth from meaningful input on major school decisions and policies.

Although the need for new forms of youth involvement and control of school may be apparent, the heightened fears and anxieties so often associated with desegregation may make this a difficult time for educators to experiment in their relationships with youth. These alternatives do exist, nonetheless. Some of the nation's pioneers in youth involvement programs argue emphatically that youth have the talent and responsibility-and the right-to be involved in creating new curricula, teaching each other in peer tutoring programs, generating special programs that meet their needs, and participating in staff selection and review. ${ }^{60}$

In desegregation situations, students have participated in citizen committees drafting desegregation plans and have served on student-faculty committees to establish and administer rules pertaining to student life in the desegregated school. ${ }^{61}$ The critical question is whether programs for youth involvement encourage student participation in crucial school decisions that affect desegregation. This is the cutting edge of new policy, an area where more substantial research could help guide new policies and programs. It also would be useful to explore the barriers to student involvement that exist within the professional structure and personnel of schools-especially secondary schools-that limit innovations in this direction. Further, at what age or grade levels are such programs most likely to be effective? The traditional distinction between elementary and secondary school students makes good sense intuitively, except that the later the introduction of responsible roles takes place, the more patterns of nonresponsibility students will have to unlearn. Research indicating what self-governing talents students have at which grade levels is needed.

The character of student rules and regulations (and of resultant discipline codes and procedures) is one area in which issues of school authority and

58. Third Year ESAA Implementation, supra note 6, at vii-15.

59. Id.

60. See, e.g., National Commission on Resources for Youth, New Roles for Youth (1974); Davies, Youth and Citizens: Allies and Collaborators, in Citizen ACtIon IN EduCation (1976); Kohler, Citizen Concern: Key to Youth Participation, in Resources for Youth Newsletter (1976).

61. FLSL, supra note 6, at 176; Oklahoma Advisory Comm. of the U.S. Comm'n on Civil Rights, supra note 11, at 63; U.S. Comm'n on Civil Rights, School Desegregation in Kalamazoo, Michigan, supra note 15 , at 15 . 
norms may come together. Thus it is a key target for change in the desegregation process. Forehand, Ragosta, and Rock indicate that, "Achievement is significantly related to perception of school fairness." 62 They argue that students' feelings about equity or fairness are so critical that they should be a major focus of desegregation programs, even superseding other goals. The nature of fairness and the actions necessary to encourage fair treatment in school are among the issues underlying student reactions to codes and other regulations.

Three areas where fairness is a problem in school rules seem to be: (1) the excessive number of rules and the resultant heavy reliance on control of youth; (2) rules that may discriminate against minority cultural traditions in language, play, work, style, and dress; and (3) the unfair administration of rules, wherein majority and minority youngsters may be caught or punished in differing degrees. Forehand and Ragosta urge educators to confront those traditions, attitudes, and rules that are barriers to equity on these issues. ${ }^{63}$ In practice, however, this is a difficult agenda on which to make progress, mostly because it cuts to the heart of the power of educators to run the school without collaboration or interference from students.

\section{Curriculum Content and Organization}

The content of schooling, as reflected in curriculum and instructional techniques, also can undergo changes during desegregation. As new groups of students with varying values and needs-as well as manifold individual differences-come together in a single environment, revised educational content may be necessary. New reading and mathematics programs, multicultural curriculum offerings, bilingual programs, classes devoted to the study and improvement of intergroup processes, and new textbooks that reflect a multicultural approach are all relevant. The USCCR notes in Fulfilling the Letter and Spirit of the Law that twenty-three of the twenty-nine case studies reported indicated curriculum changes, including multicultural or bilingual materials, vocational and career counseling curricula, and compensatory curriculum materials. ${ }^{64}$

Many school districts have experienced substantial controversy over bilingual programs and the need to recognize existing cultural differences between whites and minorities and among minority groups. If minority cultural integrity is to be cherished, and not merely temporarily tolerated and eventually assimilated, bilingual and bicultural programs are essential for any school with a sizeable number of Hispanic (or Asian or Native-American) students.

62. Forehand, Ragosta, \& Rock, supra note 6 , at 39.

63. Forehand \& Ragosta, supra note 6, at 53-56, 72-75.

64. See FLSL, supra note 6 , at table, p. 126. 
When massive transportation plans so redistribute linguistically different children that they cannot have access to such programs, something has to give. Thus, the priority on racial mixing may conflict with the priority on opportunities for maintaining and advancing cultural integrity. ${ }^{65}$

It does not seem reasonable to disperse certain groups of students so widely that they will lack friends and comrades of their own group. Some critical mass of minority students must exist in each desegregated setting; otherwise there is little protection against the marginality and alienation of being alone in others' worlds. This is an especially important principle when special programs for minorities require numbers of them to be in one place to be served adequately. Research concerning what programs should be offered to Hispanic students is not yet clear, but the expressed needs and concerns of many scholars and community members are. Special programs that teach English as a second language are important ingredients in assimilating and adapting linguistically different youngsters to the mainstream of American schooling and society. At the same time, if this program is managed in ways that deprecate or assign less significance to the students' own language and culture, it is obviously detrimental to those persons and to our plural society. Bilingual programs that instruct in the students' native languages are important in and of themselves, as aids to non-English-standardized academic performance and to cultural and linguistic integrity. It should be noted that instruction in the native language can be justified as not merely a temporary aid to youngsters making the transition to English but as a means of maintaining one end of the dual identity common to minority people in a majority institution.

Forehand, Ragosta, and Rock stress the importance of classroom study projects that focus on minorities and of explicit discussions of race-related matters in class. ${ }^{66}$ Numerous school systems have developed classes on human relations or intergroup relations, and a vast array of relevant curriculum materials is now available for these ventures. However, not all of these materials and the pedagogical techniques they may involve have been tested or even thoughtfully developed. In reviewing such efforts it seems important to stress the differences between two complementary emphases: first, the study and appreciation of minority cultures; and second, the examination of, and perhaps improvement of, patterns of interracial relations. Both are relevant class-

65. All minority groups have expressed this concern with regard to current desegregation programs. However, the focus on black-white issues often has obscured the special concerns confronted by Hispanic parents and students. For a discussion of this problem, see the articles collected in 1 Research Rev. of Equal Educ., Spring 1977; as well as those essays collected in Desegregation and Education Concerns of the Hispanic Community (1977). See also Roos, Bilingrual Education: The Hispanic Response to Unequal Education Opportunity, 42 LAW \& ConTEMP. Prob., Autumn 1978, at 111.

66. Forehand, Ragosta, \& Rock, supra note 6, at 193. 
room activities, both have relevant academic content, and both can focus on the history of whites and current white behaviors as well as on minorities. However, a focus solely on history can isolate everyone from contemporary realities; a focus solely on minorities neglects the study and analysis of equally important matters such as majority oppression, responsibility, guilt, and possibilities for change. It also is apparent that not all teachers are qualified or interested in dealing overtly with race relations in class. The staff's own legacy of racism, and of traditional educational content and techniques, makes a retraining program almost mandatory for such new curricula.

Another focus for the attention of researchers and practitioners has been classroom or school grouping procedures. Two distinct trends seem to be evident: first, several cities studied in the USCCR reports indicate that the use of tracking was abolished on the ground that tracking often leads to resegregation within the school. ${ }^{67}$ However, Forehand, Ragosta, and Rock report that ability grouping within a classroom need not necessarily result in distinct racial groups, and that such grouping often appears to be educationally effective. ${ }^{68}$ The difference in these reports is that heterogeneous and shifting ability grouping may permit students to compare and contrast themselves with close and relevant peers while permitting mobility between groups as appropriate. Schoolwide tracking systems have proven to be notoriously immobile; they often route students into early stratification patterns that also stereotype and isolate race and class groups. ${ }^{69}$

\section{Relevance of the Conflict and Consensus Models}

To attempt to create organizational change, adherents of the consensus model generally suggest that changes be initiated by top managerial personnel. From the consensus perspective, their support is so essential that few meaningful options can be taken without their approval. Other staff members and community groups may then be included as collaborators. Communication and problem-solving are seen as key resources for change.

Adherents of the conflict model, on the other hand, stress the need to include often excluded groups, such as parents and students, in the decisionmaking about implementing desegregation. From this viewpoint, although top leadership support is useful, other sources of power and legitimacy would be sought should top management not act positively. In fact, reliance on the authority of the principal is evidence that other groups are not sufficiently involved-and that both scholars and practitioners have failed to

67. Connecticut Advisory Comm. to the U.S. Comm'n on Civil Rights, supra note 15, at 35; U.S. Comm'n on Civil Rights, School Desegregation in little Rock, Arkansas, supra note 15, at 14.

68. Forehand, Ragosta, \& Rock, supra note 6, at 122.

69. See, e.g., Hobson v. Hansen, 269 F. Supp. 401 (D.D.C. 1967), aff'd sub nom. Smuck v. Hobson, 408 F. 2d 175 (D.C. Cir. 1969). 
conceive new models of shared authority and decisionmaking. From a conflict model perspective, communication and involvement are not especially useful unless they lead directly to new programs. The key resources for change are power and the mobilization of new sources of power by people who care about what is happening at school.

Adherents of both models acknowledge the critical role of professional educators. People with the consensus viewpoint see these staff groups as the highest form of public servants and feel that experts should control most local educational decisions. They regard such professionals as politically disinterested figures, who are therefore advocates of merit and equal education for all. People with the conflict view see these professionals as agents of prevailing elites, potent actors in the mystification of the educational process. In addition, they often feel that minority or poor communities must assert their power to monitor and correct the actions of professionals.

For consensus strategists, an even-handed discipline policy can be established by adults who care about the young entrusted to them. For conflict strategists, students of various groups must be involved in the generation of such rules, and in their implementation, if the rules are to be fair and if youth are to feel bound by them. It is quite rare to see students involved in exercising authority about the formal rules and regulations for their behavior in school. One of the tactics used by practitioners operating from a consensus view has been to formulate codes of student responsibility; several courts have required them as part of the desegregation plan. People operating from a conflict view find these attempts shallow, reflecting only adults' views of proper student behavior. Some students, responding to what they perceive as oppressive controls and a policy of exclusion from meaningful influence in school policy, have vigorously protested and demonstrated. ${ }^{70}$

According to Paulston, the debate between advocates of various bilingual programs is an example of the difference between conflict and consensus models of culture and education. ${ }^{71}$ Paulston sees a concern for the resocialization of linguistically different youngsters and their adoption of the dominant language and social skills as a consensus strategy; a concern for altering school programs to adapt to linguistically different youngsters and the maintenance of their distinctive languages and skills, as a conflict strategy. The choice between these long-term outcomes helps to determine the criteria for deciding which approach "works best."

70. For documentation as well as different consensus-based or conflict-based interpretations of the events, see J. DeCecco \& A. Richards, Growing Pains: Uses of School Conflict (1974); Strategies for Coping with Student Disruption, 13 School Management 45 (June 1969); Halleck, Hypotheses of Student Unrest, 50 Phi Delta Kappan 2 (1968); Rhea, Institutional Paternalism in High Schools, 3 URBan Rev. 13 (1968); Wasserman \& Reinman, Student Rebels and School Defenders, 4 URBAN REV. 9 (1969).

71. C. Paulston, Theoretical Perspectives on Bilingual Education Programs (1977). 
C. Instructional Techniques and the Structure of Classroom Activities

What kinds of innovations relevant to desegregation can take place within the environment of the classroom itself? The focus on community and organizational conditions associated with effective desegregation should not distract us from the ultimate locus of teaching and learning - the classroom. As Weinberg indicates:

Unsuccessful desegregation can be guaranteed by action of school boards and central administration; under such conditions, little constructive can occur in the classroom. Given a strong and positive policy position, however, the classroom teacher becomes the central element. ${ }^{72}$

Among the most important classroom issues are the pedagogical techniques by which teachers connect classroom racial relations and academic tasks; new techniques that alter racial interaction patterns can reduce the status inequalities created by the external environment.

Patchen and his co-workers point out that "among black students, participation in interracial classroom subgroups made small positive contributions to more friendly interactions with whites," while a nonsignificant but similar trend occurred among white students. ${ }^{73}$ These authors note that the effect of such activities was minimal, probably because the teacher did not emphasize or reward participation in them. Recent work by other groups of scholars has begun to explore and document some of the intricate issues and tactics involved in the effective multiracial classroom-such as new forms of participation and rewards.

Both Cohen and her colleagues and Lucker and his colleagues have generated a series of articles from a sequence of laboratory and field experiments in positive interpersonal relations and cooperation in the interracial classroom. ${ }^{74}$ The two series of studies are based upon experimental rather than survey methodology and reflect their authors' concerns not only to study these variables, but also to try to create new educational environments for teachers and students. They both proceed from erudite and careful extensions of the "contact hypothesis" in race relations to inquire into and plan the social conditions that may support equal status, anxiety free, mutually interdependent, and task productive contact between people of different races.

Lucker and his research group are concerned primarily with placing students in a classroom situation where interdependent learning groups require

72. M. WEINBERG, supra note 6 , at 235.

73. Patchen, Davidson, Hoffman, \& Brown, Determinants of Students' Interracial Behavior and Opinion Change, 50 Soc. of Educ. 55, 70 (1977).

74. Cohen, Lockheed, \& Lohman, The Center for Interracial Cooperation: A Field Experiment, 49 Soc. of Enuc. 47 (1976) [hereinafter cited as Cohen]. See also Lucker, Rosenfield, Sikes, \& Aronson, Performance in the Interdependent Classroom: A Field Study, 13 Am. Educ. Research J. 115 (1976). 
or permit students to teach each other and thus to experience mutually beneficial interactions. The task the students must deal with has a "jigsaw" design. First, each student learns one part of a total package of information in social studies. Then he or she must teach that part to others in the group. The authors expected performance to improve because the students were working interdependently on a task within a "cooperative reward structure." The reward structure was cooperative, presumably, because the group was working together and because no one person's grade affected any others; however, students took an individual test and received separate grades.

Lucker's study was set in several fifth and sixth grade classrooms in Texas. Approximately 80 percent of the three hundred students in the study were Anglo. There were no significant score differences between black and Mexican American youngsters, so the two groups were combined into a single minority category for analysis and reporting purposes. The students in the interdependent classroom took a pretest for general reading skills and social studies knowledge, worked in these jigsaw-designed groups for two weeks (forty-five minutes a day in four to six person groups), and then took a content-oriented post-test. The teachers of the interdependent classrooms were given special training on how to facilitate cooperative learning.

The results demonstrate to the authors' satisfaction that studentsespecially minority students-performed better on the social studies post-test in the interdependent classrooms than in the traditional ones. The Anglos' performance did not suffer, but their performance was not especially improved by this grouping program. Other studies by this group of researchers indicate that Anglos also may improve their cross-ethnic perceptions and that minorities do gain in self-confidence under these conditions. ${ }^{75}$

Cohen and her associates are primarily concerned with placing students in situations where they can produce and maintain a sense of equality with students of other races. Such a situation would be one in which whites do not dominate the interracial social interaction system. The group's prior research indicates that these situations require a collective task, a perception that minorities are competent, and the instrumental contribution of minorities to the success of the task. In order to create this situation, the researchers developed a program of expectancy training to provide special training to minority members who then teach skills to whites.

The authors created a special summer school program where students could study together at a "learning center." Subsequent to special training, both experimental (expectancy training) and control (learning center) students entered a classroom phase in which they engaged in a variety of shared learn-

75. Blaney, Stephan, Rosenfield, Aronson, \& Sikes, Interdependence in the Classroom: A Field Study 69 J. Educ. Psych. 121 (1977). 
ing tasks. The authors expected students to create and maintain new patterns of social relations because they had engineered the situation "to prevent the development of a status order based on perceived academic ability, a status order which would be closely related to the racial status order."76 Students worked in groups of four on a simulated task that called for full cooperation. The importance of the group's collective product, rather than the individual's accountability, was stressed as a basis for rewards.

The site for this study was a specially created summer school in a West Coast city. Some 145 ten- to thirteen-year-olds volunteered to participate. Approximately 55 percent of the students were black. A posttest of the group task was administered after the students had gone through expectancy training and the learning center program, and again after the four-week classroom phase of the summer school. Videotapes of group interaction were scored to assess which students dominated group interaction; self-report instruments were administered to students; and teachers rated student interaction patterns.

The results demonstrate that equal status interaction patterns had been created as a result of the expectancy training; that is, whites did not dominate group interactions. Not only were white-dominant patterns reduced but, in some circumstances, black-dominant patterns emerged during the expectancy training. The effects of these treatments were maintained through the classroom phase of the summer school.

To a certain extent, the Lucker and Cohen studies are comparable and complementary, and several interesting themes become apparent when the two are read together. First, both authors make it quite clear-in their reviews of prior work, in their own previous work, and in these studies-that new classroom options must be developed if we are to make progress in desegregated schooling. Collective tasks, creation of more nearly equal status systems, and less competitive or noncompetitive reward structures are among the key elements noted by both studies. Of course, other restructuring may be needed, but these three are clearly demonstrated. Similar efforts by Johnson and Johnson and by Slavin and his colleagues also support this general thrust. ${ }^{77}$ The Slavin team has experimented with various classroom techniques, such as "Teams-Games-Tournaments" and "Student TeamsAchievement Division," in order to group youngsters and generate tasks that reduce historic stereotyping and competition. Michaels, in his review of the relation between classroom reward structures and achievement, notes, "An ob-

76. Cohen, supra note 74 , at 50 .

77. Slavin, How Student Learning Teams Can Integrate the Desegregated Classroom, 15 INTEGRATED Educ. 56 (1977). Johnson and Johnson also have summarized and integrated prior research in this area (their own and others') in concise and useful form. See D. Johnson \& R. Johnson, Learning Together and Alone: Cooperation, Competition and Individualization (1976). 
vious shortcoming of individual reward structures (individual reward structures as well as competition) . . . is their relative ineffectiveness in strengthening such group process variables as collaboration and coordination, interpersonal attraction, and positive attitudes toward achievement."78

Second, since each student has a unique contribution to make to group learning and performance, more plural forms of peer evaluation and respect can be generated. Individual and group differences may be seen in less hierarchical and more truly plural terms, especially when different students become "experts" in information needed by all. Eventually, such pluralistic norms may be expanded to include divergent social and affective styles and relations, as well as academic skills and roles. Since task expertise is one form of power, these innovations can create new power relationships among students. ${ }^{79}$

Third, both Lucker and Cohen demonstrate that it is possible to move from the laboratory to the field setting, and they illustrate some ways of engineering the move. This is a welcome addition to the series of research studies that utilize a single method of inquiry and depend upon correlational analyses of large sets of survey data. Gross quantitative emphases often present a static analysis of inputs and outcomes and seldom focus on the microprocesses that distinguish one educational practice from another.

Fourth, both studies raise the question of just how far one can go in restructuring the racial interaction system without restructuring the classroom, and just how far restructuring the classroom can go without altering the organizational structure of the school. For instance, Lucker's schools tolerated the individualized but noncompetitive reward structure, but would they have accepted a truly collective reward structure such as the one Cohen used? In our view, her approach is far more appropriately titled noncompetitive than Lucker's is. But would the school have bought it? What else in the school would have had to be rearranged for teachers to adopt such norms of collaborative achievement? Could it have been used in "hard" courses as well as in the "soft" social studies? What supports are required for equal status relations and reorganized power relations among students to be sustained outside the classroom? Would other students not involved in this experiment accept or sabotage these forms of peer interactions? Would educators and other adults be able to adapt to these new patterns in interracial relations? Attempts to alter

78. Michaels, Classroom Reward Structures and Academic Performance, 47 Rev. OF EduC. RESEARCH. 87, 96 (1977).

79. The notion that task expertise is one of a set of bases of power was developed by J. French and B. Raven. See French \& Raven, The Bases of Social Power, in Studies in Social Power (D. Cartwright ed. 1959). For an extension of the concept and application of this notion to the classroom situation, see Jamieson \& Thomas, Power and Conflict in the Student-Teacher Relationship, 10 J. Applied Behavioral Sci. 321 (1974). 
status and power relations offer a major alternative to a reliance on increased interracial communication and collaborative tasks alone. These issues in the context of organizational structures and processes of schools lead back to many of the strategic and programmatic choices discussed earlier in this paper.

Fifth, both studies raise the question of what kinds of systematic retraining of teachers and majority-with-minority pairing of teachers and administrators must be implemented for these interracial gains to be maintained over time within the embracing structure of the schools. In his 1975 review of organizational changes required for effective integration, Orfield constantly stressed the need for teachers to teach in new ways and the need for inservice training programs to help this occur. ${ }^{80}$ This emphasis is still most appropriate.

The Cohen and Lucker studies are exciting precisely because they break new ground in identifying complex patterns of interaction that must be altered and show them to be alterable. They also point to unresolved issues in the basic structure and process of the classroom and school building and in the kinds of organizational changes that must be explored. As Cohen notes:

The production of equal status conditions is a necessary but not a sufficient condition for the improvement of black achievement in the desegregated setting. ... The revision of the classroom social structure ... has implications for the eventual re-design of classrooms in a total academic program of an integrated school. Non-competitive social structure with emphasis on group rather than individual accountability is shown as a feasible classroom arrangement. $^{81}$

\section{Individual Changes and Desegregation}

Changes in communities, organizational structures of schools, and classrooms obviously require corollary changes in the ways individuals within the school system go about their daily jobs. No major organizational changes will persist if the individuals administering such changes do not find new ways of thinking, feeling, and acting. By the same token, of course, no individual change will be maintained without support in the social network, organizational structure, and community ethos that surround individuals. Teachers, administrators, parents, and students all are deeply concerned with school change; and they all need training to perform new roles in desegregation.

One way of identifying targets for individual change is to identify the aspects of a person's behavior that can be altered and that thus might affect the course of successful desegregation. A useful list might include:

80. Orfield, supra note 39 , at 323 .

81. Cohen, supra note 74 , at 57. 
1. New ideas-about society, the community, and the school; about one's own self-interest in the long run; about race and sex and class relations; about the process of desegregation and education; about the possible directions and strategies of change.

2. New Feelings-about people of other races, or sexes or social classes; about one's own role in making changes; about oneself and one's friends, families, and peers.

3. New skills-in teaching, managing, and learning; in making changes in organizations and communities; in working with other people, especially people of other races, sexes, and social classes; in coping with conflict and crisis. ${ }^{82}$

Orfield has suggested that in-service programs should focus on altering ideas and skills. ${ }^{83}$ Coulson reports that in the schools receiving funds from ESAA, in-service training programs focusing on instructional techniques in basic (math and reading) skills were far more popular among teachers than were programs focusing on teacher awareness of intergroup relations. ${ }^{84}$ Since the programs on instructional techniques can be expected to meet the least resistance, they can be translated most directly into changes in classroom events.

A related issue in selecting ways to change individuals centers around the problem of power in the organization and community. Most efforts that focus on changing individuals involved in desegregation have dealt with teachers. It may be even more important for changes to occur among highly placed figures, such as administrators, civic leaders, and public officials. As people with power change, they can alter the organizations they direct. In Fulfilling the Letter and Spirit of the Law, the USCCR indicates that twenty-three of the twenty-nine school systems studied had a staff retraining program of some sort, ${ }^{85}$ and that at least three of the programs were in some degree mandatory. ${ }^{86}$ Most were directed at teachers, but at least seven included administrators, ${ }^{87}$ at least four included parents or local business leaders, ${ }^{88}$

82. See Chesler, Teacher Training Designs for Improving Instruction in Interracial Classrooms, $7 \mathrm{~J}$. Applied Behavioral Sci. 612 (1971)

83. Orfield, supra note 39 , at 323 .

84. Third Year ESAA Implementation, supra note 6.

85. See FLSL, supra note 6, at 126.

86. Connecticut Advisory Comm. to the U.S. Comm'n on Civil Rights, supra note 15, at 46; U.S. Comm'n on Civil Rights, School Desegregation in Berkeley, California, supra note 15, at 7; U.S. Comm'n on Civil Rights, School Desegregation in Racine, Wisconsin, supra note 15, at 12.

87. Oklahoma Advisory Comm. of the U.S. Comm'n on Civil Rights, supra note 11, at 42; U.S. Comm'n on Civil Rights, School Desegregation in Peoria, Illinois, supra note 15, at 9; U.S. Comm'n on Civil Rights, School Desegregation in Kirkwood, Missouri, supra note 29, at 12; U.S. Comm'n on Civil Rights, School Desegregation in Berkeley, California, supra note 15, at 4; U.S. Comm'n on Civil Rights, School Desegregation in Portland, Oregon, supra note 15, at 4; U.S. Comm'n on Civil Rights, School Desegregation in Ogden, Utah, supra note 15, at 3.

88. U.S. Comm'n on Civil Rights, School Desegregation in Wichita, Kansas, supra note 15, at 
and at least four included counselors. ${ }^{89}$

Regardless of their focus, most training programs for educators have operated as if the organizational context of the school were irrelevant. Few training programs deal with the individual's peer group, work team, friendship network, or family support systems. The overwhelming assumption seems to be that individual changes in ideas, feelings, or skills can be translated into new practices and outcomes without altering the interpersonal context or organizational structure within which educators operate. However, the organization that upheld non-innovative teaching will frustrate attempts to teach in innovative ways. Of course, it is easier to retain teachers, or to create and operate programs designed for this purpose, than to change the organization of schooling. Funds can be allocated, experts hired, meetings held, and a training program accomplished. Years of research suggest, however, that retrained individuals re-entering an unchanged organization will rather quickly revert to established practices-unless new organizational norms and rewards are employed to reinforce and encourage new behaviors. ${ }^{90}$

Just what is the extent and impact of in-service training programs for educators and of related programs directed toward students and community members? It sometimes seems that all the major school systems in the country, aided by most of the universities and all the General Assistance Centers, ${ }^{91}$ are conducting desegregation training programs. Coulson and his research group indicate that over 50 percent of the elementary and secondary staff included in their survey of ESAA-funded districts had received in-service training in the teaching of reading and math. Approximately a third of the staffs received training in cultural enrichment or issues in intergroup relations. Most programs were short-ten hours of training or less; ${ }^{92}$ the total number of hours spent with ancillary staff, students, and community groups was probably considerably smaller.

15; Texas Advisory Comm. to the U.S. Comm'n on Civil Rights, supra note 15, at 16; U.S. Comm'n on Civil Rights, School Desegregation in Nashville-Davidson County, Tennessee, supra note 45, at 11; Connecticut Advisory Comm. to the U.S. Comm'n on Civil Rights, supra note 15, at 18 .

89. Oklahoma Advisory Comm. of the U.S. Comm'n on Civil Rights, supra note 11 , at 41 ; U.S. Comm'n on Civil Rights, School Desegregation in Erie, Pennsylvania 6 (1977); U.S. Comm'n on Civil Rights, School Desegregation in Providence, Rhode Island, supra note 15, at 16; U.S. Comm'n on Civil Rights, School Desegregation in Greenville, Mississippi, supra note 49, at 6.

90. See generally Chesler, Dilemmas and Designs in Race Education/Training, in Race Education/Training 32 (November 1976) (Second Annual Symposium on Race/Education Training, Walter Reed Army Medical Center, Washington, D.C.).

91. Pursuant to 42 U.S.C. $\S 2000 c-2$, the Office of Education may fund assistance centers to render technical assistance in the preparation and implementation of desegregation plans. "Any public agency (other than a State educational agency of a school board) or private, nonprofit organization is eligible to submit an application" to become a General Assistance Center. Race, Sex and National Origin Desegregation Assistance Centers, 45 C.F.R. $\$ \S 180.31-180.39$ (1978).

92. Third Year ESAA Implementation, supra note 6. 
A national assessment of the kinds and extent of in-service training programs that were conducted as a part of desegregation efforts might uncover which programs, with which mix of resources, will make a difference in the life of the school. Good evaluations of in-service programs are extremely rare. Many evaluations are poorly funded and quickly done; many are conducted with locally derived postmeasures (sometimes even pre-postmeasures) of attitudes toward students, race relations, or even the training program itself. Litthe long-term evaluation of the impact of training on teachers' classroom activities is available, let alone studies of the impact of training on community and organizational innovations.

Scholars and practitioners adhering to the consensus strategy of individual change in desegregation usually stress retraining programs that involve attitude change and skill development and focus on educational and racial relationships, interpersonal styles and anxieties, or the need for information. Attempts to increase problem-solving skills, including diagnostic and data feedback capabilities and new teaching technologies, also are compatible with this approach. In addition to retraining programs, authorities' and peers' use of persuasion, reflective conversation, feedback, and modelling processes are common tactics. Generally, the consensus perspective includes the assumption that people of good will wish to make their own and others' lives better if they know what has to be done and how to do it.

Those adhering to the conflict model of individual change also use retraining programs but usually stress that educators' participation should be accountable to or monitored by consumer groups. New ideas and information are important, especially if they raise consciousness and challenge consensus assumptions about school and society. The development of new ways of teaching is important, but so are improvements in community members' skills in organizing others, running campaigns, generating power bases, and managing negotiations. Other skills needed by students and parents, as well as by educators, include changing targeted individuals or organizations through embarrassment and harassment, exposure of racism or incompetence, or mobilization of threat and power. Other tactics commonly used include the use of coercive rules and regulations, accountability and evaluation procedures, and the allocation of rewards for new behaviors.

IV

\section{Conceptual Models and Implementation Efforts: Conclusions}

This review suggests that there is a general pattern of assumptions underlying most desegregation programs and research that is more consistent with the consensus model of schools and school change than with the conflict model. The practices most likely to have been suggested and implemented assume a readiness for change in the school and community and a reservoir of pro- 
fessional and civic goodwill. Moreover, practices and programs that might have been motivated by either the consensus or the conflict approach seem to have been implemented rather consistently in ways that assume a consensus in support of desegregation. Overt resistance, covert sabotage, or unconscious opposition to desegregation by educators, public officials, and community groups seldom is considered; the continuing potency of racism and injustice often is downplayed; and structural changes usually are eschewed in favor of minor reforms.

Why is the consensus approach so dominant in current school practice regarding desegregation? Doubtless, the answers are many-and beyond the scope of this article. The question is one for philosophers, sociologists of science, and political scientists, since this bias has its roots in the social science community, as well as in society at large. The consensus model probably is more comforting, at least to relatively affluent white Americans. It supports their assumptions that their society is functioning effectively, their privileges are merited, gross injustices are being reduced, schools are operating fairly, and major problems are temporary. Substantial portions of the minority community doubtless also are pacified or temporized by that vision, as they may find in it a comforting and hopeful image of their future if not of their present.

It thus appears that each model serves different groups' political interests. Who gains from the perception that conflict is unnatural or dysfunctional? Or that consensus is the natural order? Certainly institutional managers are one such group. They generally need to control organizational processes, especially those that might alter current arrangements and their own positions. ${ }^{93}$ Effective maintenance of their power requires them to assume that their actions are "good" for themselves and others. They "require" a societal model that suggests the current order is right and proper, that this order is agreed upon, and that conflict is illegitimate or, at least, undersirable.

Who gains from the perception that conflict is natural or functional? Oppressed groups and those who would benefit from changes in the distribution of societal resources do. They must organize new resources to combat prevailing power structures. If the system is unresponsive to their needs, and appeals do not bring redress, their attempts to heighten conflict and generate threats to the prevailing order also require certain assumptions. Scholars and social movement organizers may collaborate to sustain assumptions of "system blame" for various problems and thereby justify escalated conflict and change in the larger system.

Other factors besides a group's political interests determine which model is used in a given situation. The issues at stake, and each group's perception

93. See generally L. Coser, supra note 14; W. Gamson, Power and Discontent (1968). 
and preference regarding these issues, also play a major role. For instance, according to Warren and Hyman, the basic issue in deciding which model fits best is whether or not the social system is likely to be in fundamental agreement with the desired change.

If the party attempting to bring about a change can reasonably expect that there will be no major opposition and that there is substantial agreement on the way the issue will be seen, he has much to gain by employing a collaborative strategy (consensus).

On the other hand, where there is opposition to the goal-opposition that cannot be won over through alternative strategies—one must "fight" for it or give it up (conflict). ${ }^{94}$

We need not make a case here for the better fit of the conflict model, except to say that desegregation is indeed a source or symbol of major community and organizational conflict, and that it sparks and surfaces secondary conflicts within and between communities, organizations, and individuals. Recognizing this as reality and self-consciously applying either the consensus or the conflict model (or a combination of the two) can help direct researchers and practitioners to useful new ideas and programs.

The "accuracy" of a model is probably not as important as the function it serves for the user. But the current skew in desegregation theory and planning-in favor of the consensus model-is dangerous; it works against breadth and clarity in theory and program. We need more analyses that stem from the conflict model and more that explore the full meaning of the application of the conflict model to desegregation and school change. We also need more detailed thinking and planning about educational and community programs that are consistent with the conflict model, thus providing a broader range of policy and program options. Some of these options may come closer to fitting the underlying assumptions and preferences regarding the future of schools and race relations than the options currently available. If more conscious attention is not directed to alternative models of school desegregation and to the implications of these alternatives; scholars, practitioners, and policymakers may become victims of a limited set of assumptions-their own, or others'.

We need to know more about why, how, and with what consequences effective strategies for desegregation are introduced, adopted, and implemented. Is the fact that changes in strategy such as those discussed in this article have not been developed and implemented on a broad scale attributable to a lack of knowledge? If this is the case, wider dissemination of reviews of social science research knowledge may be useful. On the other hand, if the failures of these strategies are due to a lack of goodwill, creative problem-

94. Warren \& Hyman, supra note 22, at 295-96. 
solving activities, increases in interracial interactions, and appeals to democratic values may be useful. If desegregation plans are ineffective because of a lack of skill among educators or leadership groups (or among minority or community groups), workshops, skill-training events, or the intervention of social and educational planners might be useful. Does value confusion or dissensus work against the implementation of plans? If so, clarification of values, tolerance of differences, or the development of overarching norms among school staffs and student and community groups might help. Finally, is the failure to implement desegregation strategies due to a lack of power and resources? In this case, the organization of establishment resources and the mobilization of alternative (or counterestablishment) power bases might lead to successful desegregation.

In all probability, the reader's answers to the problems of achieving successfully desegregated schools will reflect her or his current stance on the conflict and consensus models of schools and school change. The answer to this question is the third generation problem of desegregation. The first generation problem for lawyers, judges, social science researchers, and educators was how to plan for and facilitate the physical reassignment of students. The second generation problem has been to determine what was required to advance beyond physical racial mixing toward integrated schooling-interracial learning environments of high quality. The third generation problem is how to implement hunches, research findings, and practical lessons about what is important to do in desegregated schools. While there may be many arguments about tactics, the general direction of change needed is clear. Why are we so slow in implementing these changes? 